\title{
The Causes and Development of Political Violence in the Late Roman Republic
}

\begin{abstract}
Zefu Sun
Changjun High School, Changsha, Hunan 410002, China

1875246154suzz@gmail.com

ABSTRACT

This essay attempts to provide a possible perspective on a topic of long-term controversy-how the Roman country converted from a republic into an empire. By reading materials written by ancient historians, combined with some further conclusions drawn by modern scholars, the author focuses on the original motives and interests of different classes in Rome and analyzes the causes of the early Republic's political balance and its subsequent collapse, as well as the origin, the development, and the influence of political violence. The author believes that the traditional political order of the Roman Republic collapsed due to the economic impact derived from several major expansion wars in the third and second century BC. And political violence then became the coordinator and the arbiter of Roman politics. Finally, in order to accommodate the demand to establish a new balance based on political violence, with Caesar's victory in the civil war being the milestone, the Roman institution gradually evolved into a dictatorship. The author hopes that this essay could appeal to people to discard ideological or moral standpoints and analyze the imperial transformation of the Roman Republic according to the objective historical conditions and universal human nature.
\end{abstract}

Keywords: Rome, the Roman Republic, the Roman Empire, Roman economy, imperial transformation, political violence

\section{INTRODUCTION}

In modern views, a republic is generally considered more civilized and advanced than a monarchy. On the contrary, the Roman civilization underwent its transition from a republic to an empire. Is this phenomenon a historical retrogression and to any extent, inevitable? Scholars have been debating on that topic for centuries. Ronald Syme claimed that the downfall of the Roman Republic derived from its institutional defects, making the political stage prone to in-fighting and riots. Therefore, Augustus becoming the first emperor saved the Roman civilization from collapse. On the other hand, Erich Gruen thought that Rome's institution had always been functioning well and suffered from in-fighting just by coincidence. It might have been a different outcome if some political figures were replaced by hypothetical ones who had better morals or some important actions weren't conducted in the first place.

Both two scholars have given evidence to support their claim. However, from my perspective, I can't avoid noticing that frequent political violence appeared during the late Republic and considered it of great magnitude to explain Rome's imperial transition. The Roman Republic politics wasn't full of violent events at its beginning. The governing class and commoners could always achieve compromises in the Republic's early era. Through a series of secession campaigns, commoners had made the Senate set new office, make written laws to protect their rights. But violence first appeared in the Gracchi reforms in which the Gracchi brothers both got killed because they were trying to impose decrees that harmed the nobles' benefits. Why did this unprecedented violence come to happen? Why couldn't they sit down and compromise this time as they used to do? Anyway, political violence didn't vanish but continued to take place when Gaius Marius, Cornelius Sulla, and Julius Caesar had been on the political stage. What role did political violence play in confrontations that eventually turned Rome into an empire? Should the political violence during the late Republic be considered destructive all the time and be simply labeled as "evil"?

I believe this research would offer a different view to the above-mentioned debate between Ronald Syme and Erich Gruen and put more evidence on the inevitability of 
Rome's imperial transition. This is the original aim for which I decide to accomplish this paper.

\section{DISCUSSION}

\subsection{Early Conflicts and Compromises Between The Two Classes}

To recognize the causes of the political violence that appeared in the late Republic, it can be quite inspiring to skim over the history of the Republic's early period, to see how the political system functioned when violence wasn't an option in Romans' general minds.

Although political and economic conflicts between the two classes kept reigning in the Roman Republic, the commoners and the nobles still managed to address these issues peacefully through various compromises in the early period of the Republic. The most obvious instance to demonstrate the situation was Secessio plebis, a series of secessions conducted by the commoners. During these secessions, the commoners emigrated in protest altogether from Rome in defense of their economic or political rights.

The first secession began in $495 \mathrm{BC}$ when the commoners became increasingly dissatisfied with the rulership of the nobles. According to Livy, some commoners complained that while they were abroad fighting for liberty and dominion, they had been enslaved and oppressed at home by fellow-citizens [1]. After a former military officer told others that his crops were deprived, his cottage was burnt, while his creditors still stripped him of his property and carried him to prison because he couldn't repay the debts, the commoners who gathered around the pathetic man at the forum got angered and started a riot. And after seeing the Senate's inaction, they took the advice of one Sicinius and withdrew to the Sacred Mount without orders from the consuls [1]. In the end, the Senate negotiated with the deputation of the commoners and created a new office called the tribune of the people. And a compromise was set on these terms: the commoners were permitted to have their own magistrates who should be inviolable, with the right to aid the people against the consuls. No senators should be appointed to this magistracy [1].

A tribune's duty was to veto any decrees or actions from magistrates or the Senate which were considered unfavorable to the commoners, as well as be in charge of holding the plebeian council. And to ensure that a tribune was able to perform his duty, tribunes were "sacrosanct", which means no individuals could assault them during the term of office.

In $287 \mathrm{BC}$, the commoners seceded to Janiculum (a mountain in Rome) in protest again, because, after the war against the Samnites in 290 BC, the Romans had conquered large territories, and much of land had been reserved as ager publicus which the nobility was able to control and exploit as sole possessors, but including no commoners. And then a secession was instigated by the peasants who demanded a fairer distribution of land which was won during the recent Samnite war. The Senate appointed Quintus Hortensius dictator to resolve the matter. Hortensius promulgated a law called the Lex Hortensia which claimed that any decrees passed by the plebeian council would be compulsory for all Roman citizens, including the nobles [2]. This secession was the last one and closed the Conflict of the Orders after two hundred years since the first secession.

From the above-mentioned secessions, two points can be easily noticed:

1. Although there was uproar, no political participants got physically injured or killed.

2. The nobles did make significant concessions by granting new powers to the commoners.

How to explain the willingness of the Senate to make concessions? Most importantly, Rome was a city-state on a relatively small scale at that time, which means that the proportion of slaves in its population wasn't as large as it would be after its overseas expansion. Primary agricultural producers were still the commoners, also known as free farmers in terms of agriculture. Combining that in most time of the Republic, armies were recruited from these free farmer citizens, it is reasonable to conclude that the commoners and the nobles had formed a symbiotic relationship: the commoners relied on the nobles for administration and order, and the nobles relied on the commoners for agricultural production and military service. Actually, threatening not to provide military service when enemies occurred was indeed the commoners' bargaining chip in the first secession. According to Livy, when the riot was intense in Rome, "some Latin horsemen galloped up with the disquieting news that a Volscian army was advancing to attack the City" [1]. And instead of being armed up and fighting against the Volscians, the commoners refuse to arm for their country, unless they first receive a recompense [1]. In summary, with that symbiotic relationship being stable, the two classes were undetachable and forced to reach compromises when conflicts occurred.

\subsection{The Collapse of the Symbiotic Relationship}

In the first section, I mentioned that the symbiotic relationship based on economy and military service between the nobles and the commoners was key to the avoidance of political violence in the early period. And in this section, I will try to illustrate how changes that resulted from the Punic War and the Macedonian War finally led to the collapse of that symbiotic relationship.

The first point we need to focus on is the decline of the free farmer population. As I mentioned in the first section, before the Marian reforms, Rome recruited 
soldiers from citizens whose original occupations were mostly free farmers. Being a soldier was generally considered a citizen's duty instead of a profitable job. They didn't gain a satisfying payment in forms such as salary or loot share. Therefore, when these free farmers were recruited into armies and left their families for battles over years, they faced either the risk of death or the risk of bankruptcy for leaving their farmland not well cultivated. Both led to the decline of the free farmer population. According to Livy, "free farmers had been wiped out by the war" [1].

The second point is continuous land annexation conducted by the rich. Although a law called the Lex Licinia Sextia was passed to set a restriction of 500 iugera (a unit for land measurement) of land each family was allowed to rent (virtually own it), the law was never taken seriously [1]. Ironically, the Licinius who proposed this law was punished to pay a fine later for, with his son together, illegal command of 1000 iugera of land. [1] The following methods demonstrate how a noble was able to take over land more than the law permitted:

1. A rich man may create fictitious personages, claim that they had transferred their rentals to himself, and finally held most of the land openly in his own name [3].

2. When disbanded soldiers came home and found his farmland being abandoned, they would sell it at a very low price to the neighboring rich, then headed to the Rome city for subsistence [4].

3. A rich man may actively purchase farmland from free farmers, sometimes even abuse violence to force them [4].

The third point is the extensive usage of slaves in agriculture. Romans, through wars, had seized a large number of slaves. Plutarch had put in his work a record from Gaius Gracchus, one of the Gracchi brothers, described the scene his elder brother Tiberius saw when he was passing through Tuscany on the way to Numantia in Spain, that those who tilled soil or tended flocks there were barbarian slaves [3]. The nobles preferred to order slaves to work for them in fields rather than free farmers, because generally speaking, slave usage included the following advantages:

1. Slaves wouldn't be recruited into armies. Therefore, a noble who used slaves for production faced none of the risks I mentioned from which a regular free farmer was likely to suffer. That is to say, slaves were more riskresistant.

2. Slaves needed fewer materials for life, they were offered coarse food, clothes, and lodgings. A master would like to buy bachelor slaves. These slaves were forbidden to establish a family in most situations. Thus, the master could exploit them to the greatest extent without any concern about slaves' family issues.

According to Columella in his work, De Re Rustica introduced the second advantage more specifically: 200 iugera of farmland only needed to be cultivated by 8 adult male slaves. By comparison, Romans only distributed 10 iugera of farmland to every family living in a colonia. That means, if we assume a regular family at that time contained 4 people, then 200 iugera of farmland distributed to free farmers in coloniae had to be used to raise 80 people. From that, we can clearly see how the rich landowners got their profits from slavery by cutting off expenses on manpower. The table below shows the amount of slaves that flowed into Rome in particular years.

Table 1 Slave Influx into Rome [5]

\begin{tabular}{|l|l|l|l|}
\hline Time (B.C.E) & Amount & Region & Data Source \\
\hline 209 & 30000 & Tarentum & Livy 27.16 \\
\hline 204 & 8000 & North Africa & Livy 29.29 \\
\hline 197 & 5000 & Macedon & Livy 33.10 \\
\hline 167 & 150000 & Epirus & Livy 45.34 \\
\hline 146 & 55000 & Carthage & Orosius 4.23 \\
\hline
\end{tabular}

From the above three points, we may make a bold conclusion that these three changes: the decline of the free farmer population, the severe land annexation, and the great influx of slaves into Rome had harshly damaged the symbiotic relationship between the governing class and the commoners. Even though the commoners still needed political order and administration from the governing class, the nobles couldn't see the necessity, through compromise and concession, to maintain such a symbiotic relationship, as free farmers losing their land and replaced by slaves as primary producers, as well as all the rival powers already being defeated. The old political balance of Rome had been broken, but various domestic issues just rose after its expansion. What would happen in an intransigent situation if the commoners struggle for their rights which were against the nobles' benefits? Then the shadow hung over the late Republic- political violence, emerged.

\subsection{The Violence in the Gracchi Reforms}

To resolve the unfair agrarian distribution intensified in the late Republic, Tiberius Sempronius Gracchus participated in the election for the tribunate in $133 \mathrm{BC}$. Tiberius wanted to take the land illegally commanded by nobles back and re-distribute it. At the beginning of his reforms, he tried to accommodate the nobles' benefits as far as possible, by proposing a bill that ordered them to abandon their unjust acquisitions upon being paid the value, and to admit the ownership of citizens who needed assistance [3]. That bill, however, was protested by all the rich. But Tiberius became even more radical, decided to cancel the compensation for the confiscated land. The Senate drew the other tribune Octavius to their side to veto Tiberius (a bill couldn't become law unless all the 
tribunes agree). Tiberius tried to persuade Octavius but failed, then he invoked the Lex Hortensia mentioned in the first section of this paper, which admitted that every decree passed by the plebeian council would be compulsory to everyone. He asked the plebeian council to dismiss Octavius and passed his law, the Lex Sempronia Agraria.

There was still another problem: Those commoners who benefited from Tiberius' law and got ownership of land again, couldn't start to cultivate at once, for they didn't have the primitive capital_-money for seeds, tools, and livestock. Coincidentally, King of Pergamum, Attalus III died and, in his will, sent the whole kingdom to Rome. Tiberius soon proposed, without permission from the Senate, to use money from Attalus' treasury to finance those poor farmers and passed that decree through the plebeian council like he always did, invoking the Lex Hortensia.

Those actions conducted by Tiberius were meant to fail. Tiberius Sempronius Gracchus did not understand the core of the political power of his period-the collective will of the Senate. He naively thought that he could achieve anything with his inviolable office of tribune and support from the plebeian council, whose decisions were compulsory to every Roman, as all these were written in the law derived from the secessions. The office of the tribune of the people, as well as the Lex Hortensia was an outcome out of compromise and concession based on the previous symbiotic relationship between the two classes. But as I have analyzed in the second section, after drastic economic changes, this symbiotic relationship had already collapsed. What Tiberius Gracchus didn't realize was that there is always a gap between the law and reality. The law is the codification of the power, instead of its origin.

In the later year, Tiberius ran for the tribunate again but got beaten to death by irritated senators, who claimed that Tiberius Gracchus had ambition for kingship. "But the combination against him would seem to have arisen from the hatred and anger of the rich rather than from the pretexts which they alleged", according to Plutarch [3]. Tiberius assumed that the Senate would have to obey the law. Instead, the Senate chose to use political violence as a sign to refuse to compromise

Additionally, other than their willingness to use violence, how about the feasibility to conduct that? In fact, in the record of Plutarch, the riot in which Tiberius was persecuted, "the attendants of the senators carried clubs and staves which they had brought from home" [3]. As I have written in the first section, Roman armies were only recruited when a war broke out. However, the senators were able to summon private attendants, slaves to be armed, and then attacked their political enemies. They had virtually formed a gang. On contrary, although Tiberius had his advocates, they were just unorganized mobs without weaponry. In the unequal violent confrontation, the commoners didn't even get a chance to resist. This was totally a massacre, 300 advocates got killed and their bodies were thrown into the river.

Though, a contradiction can't be neglected that, Tiberius Gracchus seemed to be the one who refused to make any concession by canceling the compensation for the rich whose land was about to confiscate. However, the unwillingness of the Senate to make a compromise was even more apparent 12 years later, when the younger brother of Tiberius, Gaius Gracchus became the victim of violence. Gaius was considered a successor of his brother's political ambition, continued the reforms for land redistribution. He was elected as a tribune in $123 \mathrm{BC}$ and got killed in $121 \mathrm{BC}$. Before the day Gaius was killed, "the consul therefore ordered the senators to take up arms, and every member of the equestrian order was notified to bring next morning two servants fully armed" [6]. If the death of Tiberius could be defined as a political accident, what the nobles did to Gaius couldn't be anything else but deliberate murder!

What had the failure of the Gracchi reforms revealed in terms of Rome's political balance? After the symbiotic relationship between the nobles and commoners collapsed, the senators had no reason to continue reaching compromises. And then if anyone tried to harm their own interests, they were going to abuse violence when they thought it was necessary, while commoners were eager to find new strength to support their struggles against the governing class but felt quite desperate in front of the tremendous disparity of strength. But later, the Marian reforms brought them a beam of light.

\subsection{The Marian Reforms_— The Escalation of Political Violence}

The political violence in Rome did not end after the assassination of the Gracchi brothers but developed into a new phase. The assassination of specific political figures gradually evolved into political purges between the optimates and the populares. On the other hand, due to the military reforms implemented by Gaius Marius, he inadvertently put the army, a violent machine, on the political stage and greatly affected the politics of Rome in the future. If we want to know where such an impact originated, we must understand the specific content of the Marian reforms.

Before Gaius Marius, Rome had always been using citizen-soldiers. Citizens with property beyond a certain standard equipped themselves when a war emerged and disbanded afterward. However, as I mentioned earlier, the defect of this system was that the citizen-soldiers couldn't focus on both their occupations for subsistence and the war at the same time, which led to the risk of bankruptcy after they retired from the army. With the expansion of Rome, soldiers needed to march further and fight for a longer period in overseas provinces such as Spain, 
Greece, and Asia Minor, which increased the risk of bankruptcy. With more citizens being impoverished, they weren't able to afford personal equipment and be recruited anymore.

The solution proposed by the Senate to this issue was to reduce the property restrictions on becoming citizensoldiers and force many proletarians to join the army. The consequence was obvious, the strength of the Roman army decreased significantly. In 110 BC, Rome started a war against Jugartha, King of Numidia. The Roman army commanded by the consul Metellus was stuck in a deadlock, until 107 BC when Gaius Marius was elected consul and began his controversial reforms.

The Marian reforms primarily included two policies:

1. "Contrary to law and custom, Marius recruited many poor and insignificant men into the army" [7], and put the responsibility of supplying the army in the hands of the general.

2. Recruited soldiers wouldn't be demobilized after the war, instead, they continued to serve in the army for 16 years in total. Marius promised them land distribution and Roman citizenship after retirement.

The long-term impact of the Marian reforms, which even Gaius Marius himself did not know, was fatal to the Republic. Because it unprecedentedly created the standing army. This violent organization would not be disbanded immediately after the war anymore, making it possible for the army to participate in the politics of Rome. Also, these newly recruited proletarians had different purposes of joining the army. Unlike previous citizen-soldiers fighting out of patriotism, they would only fight for wealth and promotion. It meant that they were not loyal to the Republic, but only to the general who could lead them to victory-Marius at this time. It was not unacceptable for his soldiers to use violent deterrence for political purposes, even if it would destroy the republican system. Scholars generally consider his reforms highly significant in Rome's transformation from a republic to an empire.

In 103 BC, Lucius Appuleius Saturninus, one of the populares and an ally of Marius, proposed a law that distributed 100 iugera of land to Marius' veterans who had followed him for 7 years. The general who needed to settle his veterans would ally with the tribune to propose necessary laws. This alliance was the landmark of a dangerous transition: Before the Marian reforms, the land was distributed to the commoners in order to enable them to afford weaponry and join the army when needed. However, the beneficiaries of the land distribution were now soldiers who were already well armed! And they had been beyond the previous passive condition and became active tools to implement the land distribution. The Republic's generals were obliged to settle their veterans, but gained huge power for themselves at the same time, imposed their will on the Senate, and didn't even need to get support from the tribunate when necessary [8].

Nevertheless, things wouldn't go that easily. The optimates kept protesting against this law as distributing land to Marius' veterans actually meant to grant them Roman citizenship. For a long time, the expansion of Roman citizenship had been a sensitive political issue, because, for the residents of the whole Apennine Peninsula, Roman citizenship was actually a privilege. For example, after the victory of a foreign war, Rome took away most of the spoils, although the allied cities were asked to send the same or even more soldiers as Rome did. Gaius Gracchus once proposed to grant Roman citizenship to those who have the Latin right, and the Latin right to all other allies, but he got illegally persecuted as well known. The same end came to Saturninus because of Marius' betrayal and his law was abolished by the Senate.

In $91 \mathrm{BC}$, another tribune Marcus Licinius Drusus tried to push forward the extension of Roman citizenship. This was the last time that attempted to wake people's political conscience and rationality, implement necessary reforms through compromise and concession [8]. After the assassination of Drusus, the Italian allies got furious and knew that Rome wasn't intended to grant them Roman citizenship. The devastating Social War then broke out. Although the allies lost this war, the Roman government still decided to make concessions and extend Roman citizenship to the whole Italy, which led to the completion of the Romanization of Italy. Marius' veterans acquired citizenship and, sent to the site of Carthage to build the new colonia.

The Marian reforms escalated the political violence in Rome into potential military confrontations, it was regarded by many as the beginning of the downfall of the Republic. But if we discard the conservative and arrogant perspectives of the Roman senators, the escalation of political violence is not necessarily an evil thing. This was the first time since the nobles rejected to politically compromise after their symbiotic relationship with the commoners collapsed due to the various effects of the Roman expansion, Romans had gained substantive progress in terms of the commoners' rights, rather than covering up confrontations through hypocritical social welfare such as the grain dole. When Marius' violent deterrence was combined with Saturninus' office of the tribune, they were almost successful. Although Marius' betrayal delayed the land distribution and the extension of Roman citizenship for over ten years, we still need to recognize that the political violence that had evolved into military confrontations had indeed become new strength to support the struggle of the commoners. From this perspective, political violence had played a very positive role. But it didn't mean that the balance of the Roman political system had been brought back as political violence is never omnipotent. We are going to see more 
defects of political violence using the civil war between Gaius Marius and Cornelius Sulla as an instance.

\subsection{The Counter-attack from the Senate}

In my introduction of this paper, I questioned whether political violence should be simply defined as evil. In the last section, I wrote that "political violence has played a very positive role". However, I do not want the readers to doubt that I am going to the other extreme__advocating political violence. I believe that political violence itself is merely a neutral tool without a specific position. What role it would play depends on the people who use it and other objective conditions. Thus, in this section, I want to demonstrate what had been done with political violence by the Roman nobles, and its further impacts and historical meanings.

Lucius Cornelius Sulla was a noble and a traditionalist, once subordinate to Gaius Marius, and served as a quaestor in the Jugurthine War [9]. Marius defeated the Numidian army in 106 BC, and then Sulla, as an ambassador, successfully persuade Bocchus, Jugurtha's father-in-law, King of Mauretania (another country where Jugurtha fled for refuge), to hand over Jugurtha. People attributed the capture of Jugurtha to Sulla, which had made Marius resentful [9]. Anyway, the publicity attracted by this feat boosted Sulla's political career. Sulla participated and won in the next succession of wars including the Social War. Instead of an invincible general, Sulla was famous for twice commanding his army to march into Rome for political purposes and became, in the modern meaning, the first virtual dictator of Rome.

In $88 \mathrm{BC}$, Sulla was elected as a consul and allocated the command of the First Mithridatic War against the Pontus Kingdom. On the other hand, Gaius Marius wanted to command this war too for it was lucrative, and most importantly, might enable him to rebuild his reputation as he had become unpopular both in the optimates and the populares for his betrayal of Saturninus in 100 BC. Therefore, "Marius now allied with Sulpicius who was a tribune of the people" [9], this Sulpicius Rufus confounded all things by force and the sword, he proposed certain vicious laws, and particularly one offering to Marius the command in the Mithridatic war [9]. He also sent military tribunes at once to Nola, who were to take over the army there and conduct it to Marius. But Sulla fled, arrived at Nola earlier, and summoned his soldiers to march back to Rome. Lucius Cornelius Sulla used the army that should have been used to protect the country for his personal military command and political conflicts!

And things that happened subsequently proved the effectiveness of violent deterrence. When Sulla and his army reached Pictae (a city), a deputation comprised of 355 people wanted to negotiate with him on behalf of the
Senate. The deputation begged him not to start an attack immediately, "since the Senate had voted that he should have all his rights" [9]. His political rivals on the Marius' side were now trying to compromise. However, as long as the deputation left, Sulla assigned two subordinates to attack, he even asked his soldiers to set fire. Plutarch commented, "This is not from any calm calculation, but in a passion, and having surrendered to his anger the command over his actions...... made his entry by the aid of fire, which made no distinction between the guilty and the innocent" [9]. Gaius Marius, after failing in recruiting slaves under a promise of freedom, fled to North Africa.

As he had taken back control over the Rome city, Sulla sentenced Marius and a few other populares to death, and then proposed a bill which ordered that afterward, no propositions from a tribune could access the plebeian council without permission from the Senate. He attempted to prevent those populares from more reforms by setting this restriction [8]. The office of the tribune had always been used by the populares as a weapon against the nobles because according to the Lex Hortensia originated from the fifth secession, a tribune could theoretically do anything he wanted as he could simply send his proposition to the plebeian council and bypass the Senate. Sulla then "supervised" in person the election for the consulship in $87 \mathrm{BC}$, in which Gnaeus Octavius and Cornelius Cinna got elected eventually.

With these emergencies settled down, Sulla went eastward again to continue his command in the Mithridatic war. But to Sulla's surprise, Cinna summoned Marius back from North Africa. Marius landed at Etruscan and established another army recruited from slaves and people who newly gained citizenship, then marched into Rome again. As long as they got into the city, they started sanguinary revenge, purged a lot of opponents. Sulla himself, for his absence, got exiled and all property confiscated. Cinna suspended the constitution and continued his authoritarian rulership till his death in 84 BC. As for Gaius Marius, he died 13 days later as he was "elected" as a consul for the seventh time. Sulla temporarily put those issues aside and prioritized the war against the Pontus Kingdom. He returned to Italy after the victory, landed at Brundisium (a port city). Gnaeus Pompey and Licinius Crassus, two of the first triumvirate, joined in Sulla's camp. To be brief, they reconquered and took control over Rome. This was the third time that Rome suffered from its own army.

After the fall of the populares, an interrex was elected from the patricians in the Senate and appointed to prepare for the consulship election. But Sulla made it clear in a letter that Rome needed dictatorship to reorganize the collapsing government. And only he, Cornelius Sulla, was able to shoulder this responsibility. In the end, the interrex Lucius Valerius Flaccus appointed Sulla dictator with a special act. Then Sulla took the following actions with the supreme political power: 
1. He purged a large number of the populares who had supported Marius and Cinna, as well as other opponents. He used the word "proscribe". "Sulla at once proscribed eighty persons, without communicating with any magistrate...... He proscribed two hundred and twenty others, and then on the third day, as many more. He said that he was proscribing as many as he could remember, and those who now escaped his memory, he would proscribe at a future time. Moreover, proscriptions were made not only in Rome, but also in every city of Italy, and neither temple of God, nor hearth of hospitality, nor paternal home was free from the stain of bloodshed" [9].

2. The property of those victims who were "proscribed", as well as the land of those cities and towns who were against Sulla during the civil war, would be confiscated. Through this way, Sulla controlled a vast fortune of the whole Italy and was able to re-distribute it to his supporters, hoping that they would also support the Senate's rulership restored by him [8].

3. Sulla established coloniae to settle his veterans because he attempted to set common interests between the soldiers and the new political system he had built.

4. Sulla enlarged the Senate by adding 300 extra senators and returned the juridical power to them.

5. Sulla prohibited people who had once been a tribune to run for other magistrates. And he also reasserted that a tribune couldn't send any proposition to the plebeian council without permission from the Senate. This time, he even canceled the tribune's right to veto decrees from other magistrates and the Senate.

Sulla seemed to be the first dictatorial ruler and a virtual sovereign in Roman history. But his purpose was not to carry out infinite dictatorship but to restore the authority of the Senate and establish an aristocratic political order. Sulla was appointed dictator legibus faciendis et reipublicae constituendae causa (dictator for the making of laws and the settling of the constitution). As that name suggested, its purpose was to rebuild the republican government. And for this purpose, he temporarily needed this special extra power. He resigned from the dictatorship as long as he finished his reforms. Although he endeavored to save the republican system with the Senate being the ruling center, that system, especially the part that weakened the power of the tribunate, was in fact abolished by Pompey and Crassus shortly after his death. After all, Sula's political career has two effects. Firstly, it proved that any action to save the republican system was futile. After Rome acquired the hegemony of the Mediterranean region through expansion, the political system established according to the situation of its city-state period could no longer resolve problems of the late Republic__Pompey being elected as the consul together with Crassus in $70 \mathrm{BC}$ at the age of 35, far below the minimum age of 42 set by Sulla strongly demonstrated it. Secondly, although Sulla resigned from the dictatorship after "repairing" the republican system, his successful experience of becoming a dictator through violent deterrence had become a template for ambitious politicians in the future and set a precedent for a dictatorial reign. From this perspective, Sulla was subjectively the savior of the Republic but objectively gave the Republic a fatal blow.

Undergoing political conflicts for half a century, the Roman ruling class eventually weakened the power of the tribunate. Sulla believed that the tribunate who could bypass the Senate and implement decrees by invoking the Lex Hortensia was the essential cause of all unrest. Therefore, he prohibited the tribunate from submitting bills to the plebeian council or rejecting that of other magistrates and senators, which is basically equivalent to banning the Lex Hortensia. The role of the tribune of the people was worth pondering because it was actually endowed with a power similar to that of a monarchby inciting commoners, they could theoretically do whatever they wanted regardless of other members in the governing class. However, during these struggles in half a century, this office had not been ideally effective as a monarch due to its lack of real power except words granted by the law. The tribunate was unable to utilize the treasury: Tiberius Gracchus had to use the legacy of Attalus III in violation of the procedures in order to fund small farmers who newly acquired farmland. It also had no violent deterrence to enforce state-beneficial policies against the interests of the nobility. A tribune couldn't even guarantee his personal safety: the murder of the Gracchi brothers is the best example. This office itself was an outcome of the political compromise in the early Republic. Its seemingly supreme and sacrosanct power was based on the compromise, or to say, tolerance of the Senate. When the symbiotic relationship between the nobles and the commoners on the political stage of the early Republic collapsed after drastic economic changes, the compromise of the Senate automatically vanished, so it was only a matter of time to weaken the power of the tribunate. Thus, the Roman commoners must find new strength for their political struggles. In my opinion, the historical significance of the Marian reforms in the political development of Rome was to solve this problem — in front of an organized army, the gang violence led by the Senate lost its meaning. Private armies could be exploited by both the optimates and the populares, making the political game fairer, creating the possibility for the balance to return.

However, the overall situation was still not optimistic. When describing Sulla's horrifying massacre of political 
enemies, Plutarch said "This gave even the dullest Roman to understand that, in the matter of tyranny, there had been an exchange, but not a deliverance." [9]. During the conflicts between Marius and Sulla, both two sides slaughtered the opposing camp with the army. Such abuse of violence was just infinite in-fighting instead of effective deterrence, and impossible to establish a new balance. In geometry, a triangle is the most stable structure. Thus, from an omniscient modern view, we can clearly see the importance of introducing the third force which is about to hold all the legitimate violence in the prevention of abuse and whose duty is to maintain that balance_t the emergence of a sovereign now became reasonable and inevitable.

\subsection{The New Balance Built by Julius Caesar}

Gaius Julius Caesar's aunt was the wife of Gaius Marius, and he himself married Cinna's daughter. Such kinship made him considered a member of the populares at the beginning of his political career. He was elected as an aedile in $65 \mathrm{BC}$ and held many gladiatorial combats for the public. He also erected a monument of Marius to win the favor of the urban commoners. He became the Pontifex Maximus in $63 \mathrm{BC}$ and was sent to Hispania Ulterior as a governor in $61 \mathrm{BC}$. In $60 \mathrm{BC}$, he returned to Rome and was successfully elected as the consul for the next year. In order to struggle against the Senate and achieve his personal political goals, he established the first triumvirate with Pompey and Crassus and became the core of the alliance as he was the mediator between them.

Caesar never gave up an option of violence against the Senate, but he did not actually hate the nobility to which he himself belonged. In fact, he was on the side of the populares merely in pursuit of personal wealth, status, and honor. Cicero once commented on him that "he wasted all the power of genius, which he had in a most brilliant degree, in a capricious purchase of popular favor. Here, as he had not sufficient respect for the sense and the virtual part of the cities, he opened for himself that path for the extension of his power" [10]. The first triumvirate was proved effective. The three great figures all had the experience of serving as provincial governors, which meant that they had their own private army. The three men enacted and enforced many laws through violence. For sensitive reasons, there are few specific records upon how they utilized violence, but basically agitating riots, street violence, and death threats. An excerpt from one letter written by Cicero to another noble, Cornelius Lentulus showed the nobles' general attitude and thoughts when subordinating to the first triumvirate: "I should have entertained the same sentiments, if I had been still perfectly uncommitted and free to choose. For I should not have thought it right to fight against such overwhelming power...... when circumstances were changed and the feelings of the loyalists altered, but rather to bow to circumstances." [11].

Now I would like to add an independent paragraph to clarify why an army couldn't be commanded by the collective will of the Senate. Firstly, during a war, the army needs a decisive commander to make rapid strategies based on the already available information. However, the Senate was essentially just a political organization, and disputes existed among the senators. Therefore, it was hard for them to draw a conclusion in emergencies. In fact, before the Marian reforms, the citizen-soldiers were commanded by two consuls, and they alternated as the supreme commander every day to give accurate orders to the army. However, in the late Republic, the army would not be dissolved immediately after the war. If a particular senator were designated to command the army, he would become a new warlord-which wouldn't be allowed by the organizational logic of the Senate. Secondly, the Senate was not responsible for the future of the soldiers. But after the Marian reforms, the general needed to endeavor to settle down his veterans_-Marius had once allied with the tribune Saturninus to propose laws on the distribution of land to his veterans. However, if a general were replaced by the whole Senate, it would likely result in "the tragedy of the commons", because the army did not directly belong to any single senator, none of the senators would be willing to take that troublesome responsibility. Veterans would become "the common parcel of land". The Senate would be willing to exploit them, but would not take care of their benefits. Under such circumstances, no soldiers seeking wealth and promotion would follow the Senate. Although Sulla's private army once launched a civil war for the Senate and the republican system, the army was only loyal to Sulla, not the whole Senate, and Sulla indeed became a warlord and a dictator. In the absence of a central figure similar to Sulla in the Senate, it was theoretically impossible for the Senate under control of the first triumvirate to duplicate the precedent and command an army for resistance.

In $59 \mathrm{BC}$, Caesar gained governorship of three provinces: Cisalpine Gaul, Transalpine Gaul, and Illyria. Then he launched the Gallic War. "In Gaul, he rifled the chapels and temples of the gods, which were filled with rich offerings...... By this means gold became so plentiful with him" [12]. With this vast fortune, he rewarded his soldiers_- "He doubled the pay of the legions in perpetuity...... sometimes distributing to every soldier in his army a slave, and a portion of land." [12], and at the same time, won the gratitude from the nobility__Every person about him, and a great part likewise of the senate, he secured by loans of money at low interest"[12]. His behaviors towards the Senate included both violent deterrence and ingratiation, which proved that Caesar wasn't either one of the optimates or one of the populares, but an independent force. However, the expansion of Caesar's influence aroused the vigilance 
of the Senate and Pompey. Pompey suspected that Caesar would threaten his status and authority. At the same time, the Senate believed that an individual with great power and influence was a threat to the republican system. Therefore, Pompey allied with the Senate to struggle against Caesar. Then in 50 BC, Caesar was ordered by the Senate to disband his army and return to the Rome city. He was afraid that he might be brought before the court and persecuted as he was not on the term of any office. He tried to compromise by proposing that either he kept his governorship until he could be elected as a consul again in $48 \mathrm{BC}$, or Pompey was dismissed from his governorship and demobilized his army as well. Pompey and the Senate, however, both rejected to make any compromises. In Cicero's letter to his friend Atticus, he wrote that when Pompey talked about the current political situation, he felt that a civil war became already inevitable [13]

I assume that, at this time, the political violence in Rome had developed to the final phase: mutual attack and annexation between warlords. From the perspective of political violence, the inevitability of civil war was reflected in two points: Firstly, the person who can master a loyal army and use this army to achieve violent deterrence for political purposes must be an ambitious and domineering man, such as Caesar and Pompey. They would not allow themselves to be inferior or subordinate to any others. Although in terms of probability, such people will appear in whichever period, the objective political environment of the late Republic provided them with the opportunity to become dominant. Secondly, the Senate would not willingly yield to violent deterrence. When they had seen the discord between Caesar and Pompey, they would win over one of them and try to provoke their fight in an attempt to restore their authority. The Senate only temporarily courted Pompey to help themselves against Caesar. They imagined that once Pompey lost the support of his all and the populares, his power would be weakened and eventually controlled by them.

In $49 \mathrm{BC}$, Caesar crossed the Rubicon river- the frontier boundary of Italy, with only a single legion, ignited the civil war. Pompey, however, did not await his approach, but fled to Brundisium, sent the consuls before him with an army to Dyrrhachium, and shortly sailed off himself [14]. Anyway, Pompey didn't survive for a long time, he was decisively defeated by Caesar at Pharsalus, Greece, in $48 \mathrm{BC}$, fled again to Egypt but was assassinated. That's the dramatic end of Pompey the Great.

After winning the civil war and obtaining the supreme power in Rome, Caesar began his dictatorship. His ruling style was completely contrary to that advocated by the republican system. His rule was based on the help of talented administrative officials and the cabinet. These officials did not belong to the Senate and were not important in the original political life. Caesar had deprived the Senate of power. Although it was retained as an institution, this ancient ruling class was no longer the center of power in Rome. Decrees proposed by the dictator would be submitted to the Senate and the council according to procedures, but this was nothing more than a disguise. Cicero once wrote in his letter in a humorous and ironic tone, said that, "Do you think there will be fewer decrees of the Senate if I am in Naples? When I am in Rome and often in the forum, decrees of the senate are written at the home of your admirer, my intimate acquaintance; indeed, when it occurs to him, I am put down as present at their drawing up, and I hear of a senatorial decree, said to have been passed on my motion, reaching Armenia and Syria, before I hear so much as a mention of the matter itself. And I don't want you to think that I am joking. I should tell you that letters have been brought to me from kings at the ends of the earth, in which they thank me for proposing the motion to give them the title of kings, when I was not only unaware of their royal appellation, but even of their very existence." [11].

At the same time, Caesar managed to eliminate the conditions where street violence originated. He prohibited citizens to form collegia for these collegia had provided organizations for violent behaviors driven by political motives. And he also ensured that no one could abuse violence for political power. These reforms during his dictatorship had totally different purposes, definitely not to rescue the collapsing Republic but merely to consolidate Caesar's dictatorship [8]. On the contrary to Sulla, he originally only wanted to assure his status and political career through negotiation, instead of focusing on restoring the Republic in any form. That's why he was interested in preventing revenge and punishment. As can be seen from that he pardoned a lot of his enemies in the civil war. Caesar concentrated violence in his own hands, prevented the spread of violence in the society, and made the Republic gradually move towards stability after a century of chaos. Even though he was the greatest warlord in Rome, he was quite restrained in violence usage: Although the concerned personages tried to let him overuse the legitimate power granted to him and dispose of the defeated enemies at his own will, he could always resist these temptations [8]. Caesar's actions were mostly correct. In the phrase "violent deterrence", "violent" is the attribute of "deterrence". In other words, the core of this concept is still "deterrence" rather than the simple abuse of violence. Just like the role played by nuclear deterrence in the world after World War II, the key to violent deterrence is that the deterred object is aware of the existence of violence and the potential possibility of usage, while the subject who controls violence will not abuse it. If violence is abused, the deterred object will resist and lead to the failure of the deterrence as it will be injured anyway_ if any country in the world indiscriminately uses nuclear weapons, all other countries 
will abandon the existing order and launch a destructive nuclear war.

During his term of dictatorship, Caesar also maintained the political balance in terms of different interests. In $49 \mathrm{BC}$, he granted citizenship to the people living in Transalpine Gaul to appreciate their support in the Gallic War. And nobles who were exiled for political reasons during Pompey's third consulship were gradually recalled to Rome according to special laws. They then became Caesar's grateful clients. And when Caesar enforced these laws, he barely faced any hindrance due to general obedience out of the fear of violent deterrence. In Cicero's work, he claimed that "He (Caesar) had conciliated the ignorant multitude by presents, by monuments, by largesses of food, and by banquets; he had bound his own party to him by rewards, his adversaries by the appearances of clemency. Why need I say much on such a subject? He had already brought a free city, partly by fear, partly by patience, into a habit of slavery." [10].

\section{CONCLUSION}

In the early Roman Republic, the reason why the nobles and the commoners could reach compromises and concessions was the symbiotic relationship based on agricultural production and military recruitment. The commoners implemented deterrence through secessions for political and economic rights. However, the overseas expansion of Rome in the third and the second century $\mathrm{BC}$ led to the collapse of the original symbiotic relationship. Therefore, it was no longer necessary for the ruling class to compromise and make concessions with the lower class. When the commoners and their political representatives, such as the Gracchi brothers, struggled for rights, the nobles would ignore the laws based on the previous symbiotic relationship and use violence. After the Marian reforms, the emergence of the virtually private standing army escalated political violence from street violence to military confrontations. The army itself was not an organization with a specific political position. It could be used by both the optimates and the populares for political purposes, which led to several civil wars. Sulla once managed to restore the republican system through violent deterrence. But after Sulla's death, warlords, such as the first triumvirate, appeared on the political stage as the third force. The warlords had no specific fixed factions, and their actions were only to realize their ambition. They eventually mutually attack out of exclusivity. Finally, Gaius Julius Caesar became the last warlord to survive in the first triumvirate and used violent deterrence to impose his own policies without hindrance. Both the optimates and the populares were subject to Caesar's violent deterrence. Caesar took into account the interests of different factions, and then successfully rebuilt a new balance. Although Caesar was assassinated by some senators soon after, the precedent he created became a template for the future emperors of the Roman Empire and laid the foundation for the Republic's transition towards an empire.

\section{REFERENCES}

[1] Livius, T. The History of Rome.www.perseus.tufts.edu/hopper/text?doc=Pers eus:text:1999.02.0026

[2] Lintott, A. (2016) The Constitution of the Roman Republic. Translated by Shaoxiang Yan. The Commercial Press, Beijing.

[3] Plutarchus, L.M. Parallel Lives-Tiberius Gracchus.https://penelope.uchicago.edu/Thayer/E/ Roman/Texts/Plutarch/Lives/Tiberius_Gracchus*.h tml

[4] Appianus. The Civil Wars.http://www.perseus.tufts.edu/hopper/text?doc =Perseus:text:1999.01.0232

[5] Yang, Gongle. (2010) An Economic Study on the Roman Society. Beijing Normal University Publishing Group, Beijing.

[6] Plutarchus, L.M. Parallel Lives-Gaius Gracchus.http://www.perseus.tufts.edu/hopper/text ?doc=Perseus:text:1999.01.0232

[7] Plutarchus, L.M. Parallel Lives-Gaius Marius.https://penelope.uchicago.edu/Thayer/E/Ro man/Texts/Plutarch/Lives/Marius*.html

[8] Bingmann, K. (2014) A History of the Roman Republic. Translated by Zhi Liu. East China Normal University Press, Shanghai.

[9] Plutarchus, L.M. Parallel Lives-Cornelius Sulla.

[10] https://penelope.uchicago.edu/Thayer/E/Roman/Te xts/Plutarch/Lives/Sulla*.html

[11] Cicero, M.T. Philippics.http://www.perseus.tufts.edu/hopper/text ?doc=Perseus:text:1999.02.0021

[12] Cicero, M.T. Letters.www.perseus.tufts.edu/hopper/text?doc=Per seus:text:1999.02.0022

[13] Tranquillus, G.S. The Lives of the Caesars.http://www.perseus.tufts.edu/hopper/text?d oc=Perseus:text:1999.02.0132

[14] Cicero, M.T. Letters to Atticus.www.perseus.tufts.edu/hopper/text?doc=Pe rseus:text:1999.02.0008

[15] Plutarchus, L.M. Parallel Lives-Julius Caesar.https://penelope.uchicago.edu/Thayer/E/Ro man/Texts/Plutarch/Lives/Caesar*.html 
[16] Goldsworthy, A. (2016) In the Name of Rome: The Men Who Won the Roman Empire. Yale University Press, New Haven.

[17] Matthew, C.A. (2010) On the Wings of Eagles: The Reforms of Gaius Marius and the Creation of Rome's First Professional Soldiers. Cambridge Scholars Publishing, Newcastle upon Tyne.

[18] Li, Yining. (2015) An Economic Study on RomeByzantine. The Commercial Press, Beijing. 